\title{
VIVIANITE FROM PAAKKILA, TUUSNIEMI, FINLAND
}

\begin{abstract}
AHTI SIMONEN
SIMONEN, AHTI, 1986: Vivianite from Paakkila, Tuusniemi, Finland. Bull. Geol. Soc. Finland 58, Part 1, 271-275.

Mineralogy of vivianite from Paakkila is presented, including physical properties $\left(\alpha=1.580, \beta=1.606, \gamma=1.636,2 \mathrm{~V}_{\gamma}=86^{\circ}\right.$ and Sp.gr. $\left.=2.695\right)$ and chemical composition. The studied vivianite occurs as euhedral greenish blue crystals in a pyrrhotite-bearing vein and it is partly oxidized (28\% of the total iron) with $\mathrm{Fe}^{+2} / \mathrm{Fe}^{+3}=2.57$. The chemical formula of studied vivianite is $\mathrm{Fe}_{2.2}^{+2} \mathrm{Fe}_{0.8}^{+3}$ $\left(\mathrm{PO}_{4}\right)_{2}(\mathrm{OH})_{0.8} \cdot 7.2 \mathrm{H}_{2} \mathrm{O}$. Different types of vivianite occurrences in Finland are briefly discussed.
\end{abstract}

Key words: vivianite, optical properties, chemical composition, Finland.

Ahti Simonen: Otakuja 3 D 46, SF-02150 Espoo, Finland.

\section{Discovery}

In year 1952 the students of geology in the University of Helsinki made an excursion to the asbestos mine of Paakkila in northern Karelia. During this visit a blue-coloured mineral was found and the leader of the excursion, Professor Dr. Pentti Eskola, gave the collected material to the disposal of the present author for identification.

The preliminary X-ray diffractometer studies indicated that the discovered blue-coloured mineral was vivianite. Later both optical and chemical properties of the mineral were determined. Now after 34 years from the discovery of the vivianite in Paakkila, the present author as emeritus found when cleaning drawers his old determinations of vivianite. The chemistry and physical properties of the mineral are given in this study to increase a rather purely known data of vivianite in Finland.

\section{Occurrence}

The Precambrian bedrock of the Paakkila area is characterized by small lenses of ultrabasic anthophyllite - asbestos - serpentine rocks which are surrounded by migmatitic mica gneisses and granites. Vivianite has been found in the asbestos mine of Paakkila. The crystals of vivianite occur along the margin of a narrow metalliferous, pyrrhotite - bearing vein which penetrates the ultrabasic rock consisting mainly of actinolite and serpentine.

Vivianite occurs as elongated tabular euhedral to subhedral crystals which are randomly or partly radially arranged along the contact plane between the metalliferous vein and the ultrabasic rock (Fig. 1). The crystals are flattened along $\{010\}$ and elongated parallel to the crystallographic c-axis. The perfect cleavage which is $\{010\}$ is parallel to the contact plane of the vein. The largest crystals are up to $1-1.5 \mathrm{~cm}$ in length. 


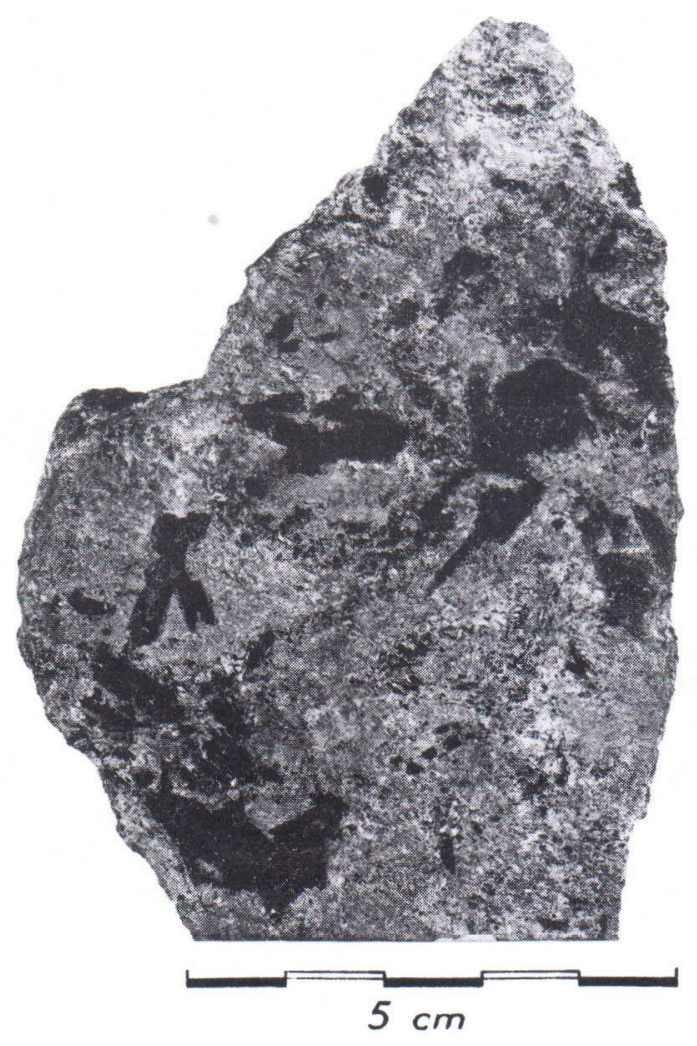

Fig. 1. Vivianite crystals (dark). Paakkila, Tuusniemi. Photo E. Halme.

\section{Physical properties}

The colour of the vivianite studied is greenish blue. The streak is pale bluish but the colour is soon changing dark blue due to oxidation. The specific gravity determined by pycnometer is 2.695 .

The refractive indices of vivianite were determined by means of immersion method in sodium light at $20^{\circ} \mathrm{C}$ and the optic axial angle was measured on an universal stage. The optical properties of the vivianite from Paakkila are as follows:

$$
\begin{aligned}
& \alpha=1.580 \pm 0.002 \\
& \beta=1.606 \pm 0.002 \\
& \gamma=1.636 \pm 0.002 \\
& 2 \mathrm{~V}_{\gamma}=86^{\circ} \pm 2^{\circ} \\
& 2 \mathrm{~V}_{\gamma} \text { (calc.) }=87.4^{\circ}
\end{aligned}
$$

The pleochroism is strong with:

$$
\begin{aligned}
& \mathrm{X}=\text { blue } \\
& \mathrm{Y}=\text { pale bluish green } \\
& \mathrm{Z}=\text { pale yellowish green }
\end{aligned}
$$

The optical properties of vivianite vary within wide limits depending on the content of ferric iron caused by oxidation. With increasing oxidation the refractive indices increase, and the pleochroism becomes stronger as shown by Fig. 2 . The optical properties of the vivianite from Paakkila are related to those of many partly oxidized $\left(\mathrm{FeO}>\mathrm{Fe}_{2} \mathrm{O}_{3}\right)$ vivianites and especially they are very close with those of the vivianite from Mullica Hill, New Jersey $(\alpha=1.579, \beta=1.603$, $\gamma=1.633,2 \mathrm{~V}=85^{\circ}$ ) referred by Zieleniewski (1945). Indices of refraction of triclinic metavivianite $(\alpha=1.579, \beta=1.603, \gamma=1.629)$ given by Ritz et al. (1974) are only little lower than those of the vivianite from Paakkila.

\section{X-ray studies}

The vivianite from Paakkila was identified by $\mathrm{X}$-ray diffractometer. The powder pattern was recorded with a Philips X-ray diffractometer with $\mathrm{Co}$ radiation. The strongest $\mathrm{d}$-spacing of the diffractogram is $d=6.80$ and other rather strong spacings are $\mathrm{d}=1.68, \mathrm{~d}=2.72, \mathrm{~d}=3.21, \mathrm{~d}=$ 4.1 and $d=8.02$. The diffraction pattern of the

Table 1. Chemical composition of vivianite from Paakkila, Tuusniemi. Analyst, Pentti Ojanperä.

\begin{tabular}{lrrll}
\hline Constituent & wt. \% & Mol.prop. & \multicolumn{2}{c}{$\begin{array}{c}\text { Atoms/unit } \\
\text { cell* }\end{array}$} \\
\hline $\mathrm{SiO}_{2}$ & 0.62 & .0103 & $\mathrm{Si}$ & 0.05 \\
$\mathrm{TiO}_{2}$ & 0.03 & .0004 & $\mathrm{Ti}$ & 0.00 \\
$\mathrm{Fe}_{2} \mathrm{O}_{3}$ & 13.16 & .0824 & $\mathrm{Fe}^{+3}$ & 0.84 \\
$\mathrm{FeO}$ & 30.53 & .4249 & $\mathrm{Fe}^{+2}$ & 2.16 \\
$\mathrm{MgO}$ & 0.00 & .0000 & $\mathrm{Mg}$ & 0.00 \\
$\mathrm{MnO}$ & 0.00 & .0000 & $\mathrm{Mn}$ & 0.00 \\
$\mathrm{CaO}$ & 0.05 & .0009 & $\mathrm{Ca}$ & 0.01 \\
$\mathrm{P}_{2} \mathrm{O}_{5}$ & 27.94 & .1968 & $\mathrm{P}$ & 2.00 \\
$\mathrm{H}_{2} \mathrm{O}^{+}$ & 16.64 & .9236 & $\mathrm{H} \mathrm{H}_{2} \mathrm{O}$ & 7.07 \\
$\mathrm{H}_{2} \mathrm{O}^{-}$ & 11.36 & .6361 & $(\mathrm{OH})$ & 0.84 \\
\hline Total & 100.33 & & & \\
\hline
\end{tabular}

* calculated on the basis of two phosphorus atoms/unit cell 
vivianite from Paakkila is closely related to that given on the JCPDS card (3-0070).

\section{Chemical composition}

Material for the wet chemical analysis (Table 1) was picked from the flakes of a crushed vivianite crystal. The purity of the material was tested under the microscope by means of an immersion liquid of approximately the same index of refraction as the mineral itself. The amount of foreign grains (mainly quartz) was estimated to be less than 1 per cent.

Vivianite is a monoclinic ferrous phosphate rich

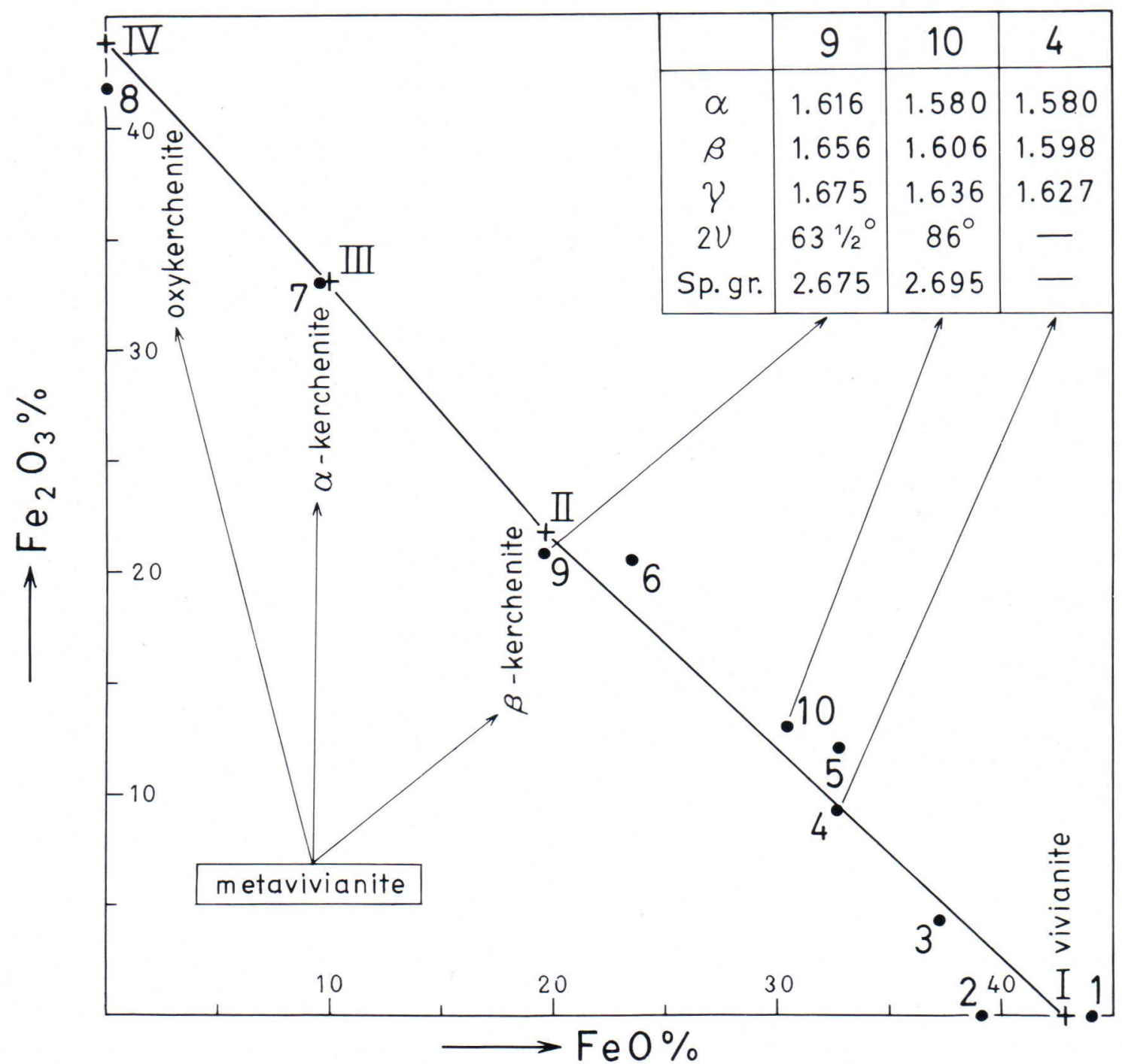

Fig. 2. The percentages of $\mathrm{FeO}$ and $\mathrm{Fe}_{2} \mathrm{O}_{3}$ in vivianite and physical properties of some analyzed vivianites.

$\mathrm{I}$, vivianite $\mathrm{Fe}_{3}^{+2}\left(\mathrm{PO}_{4}\right)_{2} \cdot 8 \mathrm{H}_{2} \mathrm{O}$;

II, $\beta$-kerchenite $\mathrm{Fe}_{4}^{+2} \mathrm{Fe}_{4}^{+3}(\mathrm{OH})_{4}\left(\mathrm{PO}_{4}\right)_{6} \cdot 21 \mathrm{H}_{2} \mathrm{O}$;

III, $\alpha$-kerchenite $\mathrm{Fe}_{2}^{+2} \mathrm{Fe}_{6}^{+3}(\mathrm{OH})_{6}\left(\mathrm{PO}_{4}\right)_{6} \cdot 18 \mathrm{H}_{2} \mathrm{O}$;

IV, oxykerchenite $\mathrm{Fe}_{8}^{+3}(\mathrm{OH})_{8}\left(\mathrm{PO}_{4}\right)_{6} \cdot 17 \mathrm{H}_{2} \mathrm{O} ; 1-8$,

chemical analyses referred in Dana's system of mineralogy (Palache et al. 1951); 9, Ibex mine, Leadville (Zieleniewski 1945); 10, Paakkila, Tuusniemi. According to recent studies by Dormann and Poullen (1980) kerchenites are classified as metavivianite. 
in water with the chemical formula $\mathrm{Fe}_{3}\left(\mathrm{PO}_{4}\right)_{2}$. $8 \mathrm{H}_{2} \mathrm{O}$. The greatest variations in the chemistry of vivianite, as found by various research workers, occur in the contents of $\mathrm{FeO}$ and $\mathrm{Fe}_{2} \mathrm{O}_{3}$, whereas the contents of $\mathrm{P}_{2} \mathrm{O}_{5}$ and $\mathrm{H}_{2} \mathrm{O}$ do not vary greatly. However, the dehydration of vivianite starts already at $40^{\circ} \mathrm{C}$ (Zieleniewski 1945). Only small amounts of $\mathrm{Mn}^{+2}, \mathrm{Mg}$ and $\mathrm{Ca}$ substitute for $\mathrm{Fe}^{+2}$. The content of $(\mathrm{CaO}+\mathrm{MnO}+$ $\mathrm{MgO}$ ) is usually less than 5 per cent. Fig. 2 shows that the composition of vivianite passes gradually from ferroan vivianites into partly $(\mathrm{FeO}>$ $\left.\mathrm{Fe}_{2} \mathrm{O}_{3}\right)$ and highly oxidized $\left(\mathrm{FeO}<\mathrm{Fe}_{2} \mathrm{O}_{3}\right)$ vivianite and metavivianite (= kerchenites).

Vivianite from Paakkila (Table 1 and Fig. 2) with $\mathrm{Fe}^{+2} / \mathrm{Fe}^{+3}=2.57$ is a typical representative of partly oxidized vivianites. In addition, it contains only very small amounts of Ca substituting for $\mathrm{Fe}^{+2}$, whereas $\mathrm{Mg}$ and $\mathrm{Mn}$ are totally lacking. The chemical formula calculated from the chemical analysis is as follows:

$\mathrm{Fe}_{2.2}^{+2} \mathrm{Fe}_{0.8}^{+3}\left(\mathrm{PO}_{4}\right)_{2}(\mathrm{OH})_{0.8} \cdot 7.2 \mathrm{H}_{2} \mathrm{O}$.

\section{Vivianite in Finland}

Only very few notes on the occurrence of vivianite in Finland have been reported ( $c f$. A. Laitakari 1967) and the physical and chemical properties of the Finnish vivianites are very purely known.

\section{References}

Dormann, J. \& Poullen, J., 1980. Étude par spectroscopie Mössbauer de vivianites oxydées naturelles. Bull. Mineral. $103,633-639$.

Haapala, I., 1966. On the granite pegmatites in the Peräseinäjoki-Alavus area, south Pohjanmaa, Finland. Bull. Comm. géol. Finlande 224, 98 p.

Kallio, P. \& Alviola, R., 1975. Triphylites and lithiophilites from the granite pegmatites of the communes of Kitee and Tohmajärvi, E. Finland. Fortschr. Miner. 52, Spec.
So far as known, the first notice of the occurrence of vivianite in Finland was made by A. Nordenskiöld (1855). He reported that some clay deposits of southern Finland (for example Korsmossan in Dregsby, Porvoo) contain bluecoloured iron phosphate.

Most of the vivianite occurrences in Finland have been found in granite pegmatites as alteration products of iron-bearing phosphates triphylite, lithiophilite and alluaudite (Volborth 1954, Haapala 1966, Kallio \& Alviola 1975, and Lahti 1981). Haapala (1966) has given the optical properties $(\alpha=1.593, \beta=1.614, \gamma=1.650$, $\left.2 \mathrm{~V}_{\gamma}=75^{\circ}\right)$ of the vivianite from the pegmatite in Hunnakko, Alavus. Kallio \& Alviola (1975) have reported the results of a microprobe analysis $(\mathrm{FeO}=42.6, \mathrm{MnO}=5.8, \mathrm{MgO}=0.0, \mathrm{CaO}=$ $0.2, \mathrm{P}_{2} \mathrm{O}_{5}=33.2$ ) of the vivianite from the pegmatite in Oriselkä, Tohmajärvi.

The vivianite from Paakkila, described in this paper, represents a new type of occurrence of vivianite in Finland. It does not occur in granite pegmatites, but is connected with a metalliferous vein.

Acknowledgements. The author is indebted to Mr. Pentti Ojanperä, M.Sc., for chemical analysis; to Mr. Erkki Halme for taking the photograph; to Mrs. Elsa Järvimäki for drawing the diagram; and to Mrs. Helga Leppänen for typing the manuscript. Dr. Seppo Lahti read the manuscript critically and gave valuable suggestions.

The author expresses his cordial thanks to all above persons for their help.

Issue: IMA-papers, $9^{\text {th }}$ meeting Berlin-Regensburg 1974, 279-283.

Lahti, S., 1981. On the granite pegmatites of the Eräjärvi area in Orivesi, southern Finland. Geol. Surv. Finland Bull. 314, $82 \mathrm{p}$.

Laitakari, A., 1967. Suomen mineraalien hakemisto - Index of Finnish minerals with bibliography. Bull. Comm. géol. Finlande 230, 842 p.

Nordenskiöld, A., 1855. Beskrivning öfver de i Finland funna mineralier. Finska Litteratur-sällskapets tryckeri. Helsingfors. 
Palache, C.; Berman, H. \& Frondel, C., 1951. Dana's system of mineralogy. Volume II, $7^{\text {th }}$ edition. John Wiley and Sons, Inc. New York.

Ritz, C.; Essene, E. \& Peacor, D., 1974. Metavivianite, $\mathrm{Fe}_{3}\left(\mathrm{PO}_{4}\right)_{2} \cdot 8 \mathrm{H}_{2} \mathrm{O}$, a New Mineral. Am. Mineral. 59, $896-899$.
Volborth, A., 1954. Phosphateminerale aus dem Lithiumpegmatit von Viitaniemi, Eräjärvi, Zentral-Finnland. Ann. Acad. Sci. Fennicae A III, 39, 90 p.

Zieleniewski, S., 1945. O wiwianitach bagiennych niźu polskiego. Arch. Min. Soc. Warsaw 15, 56 p. 